\title{
Resistance in Mango Against Infection by Ceratocystis fimbriata
}

\author{
Leonardo Araujo, Wilka Messner Silva Bispo, Isaías Severino Cacique, \\ Wiler Ribas Moreira, and Fabrício Ávila Rodrigues
}

Viçosa Federal University, Department of Plant Pathology, Laboratory of Host-Pathogen Interaction, Viçosa, Minas Gerais State, 36570-900, Brazil.

Accepted for publication 10 February 2014.

\section{ABSTRACT}

Araujo, L., Bispo, W. M. S., Cacique, I. S., Moreira, W. R., and Rodrigues, F. A. 2014. Resistance in mango against infection by Ceratocystis fimbriata. Phytopathology 104:820-833.

This study was designed to characterize and describe host cell responses of stem tissue to mango wilt disease caused by the fungus Ceratocystis fimbriata in Brazil. Disease progress was followed, through time, in inoculated stems for two cultivars, 'Ubá' (field resistant) and 'Haden' (field susceptible). Stem sections from inoculated areas were examined using fluorescence light microscopy and transmission and scanning electron microscopy, coupled with energy-dispersive X-ray microanalysis. Tissues from Ubá colonized by $C$. fimbriata had stronger autofluorescence than those from Haden. The X-ray microanalysis revealed that the tissues of Ubá had higher levels of insoluble sulfur and calcium than those of Haden. Scanning electron microscopy revealed that fungal hyphae, chlamydospores (aleurioconidia), and perithecia-like structures of $C$. fimbriata were more abundant in Haden relative to Ubá. At the ultrastructural level, pathogen hyphae had grown into the degraded walls of parenchyma, fiber cells, and xylem vessels in the tissue of Haden. However, in Ubá, plant cell walls were rarely degraded and hyphae were often surrounded by dense, amorphous granular materials and hyphae appeared to have died. Taken together, the results of this study characterize the susceptible and resistant basal cell responses of mango stem tissue to infection by $C$. fimbriata.

Additional keywords: barrier zones, phenolic-like compounds, vascular pathogen.
Worldwide, mango (Mangifera indica L.) is one of the most important tropical fruit crops (22). The adaptability of mango cultivars to different environmental conditions and their resistance to multiple diseases are among the factors that greatly improve mango quality and yield (12). Mango wilt is caused by Ceratocystis fimbriata Ellis \& Halst. $(23,56)$ in Brazil $(40)$, while a similar wilt disease is found in Oman and Pakistan, where it is attributed to $C$. manginecans $(1,55)$. Thus, mango wilt has become a serious concern to growers $(1,55)$. $C$. fimbriata causes death of the entire tree either a few months after the fungus penetrates the roots or more slowly if it enters through wounded branches of the canopy (40). Typical disease symptoms include wilting and browning of leaves on single branches and gum exudation from the trunks $(40,56)$. As the infection progresses, the internal and external stem tissue becomes dark brown due to intensive necrosis $(40,56)$.

The eradication of mango trees with wilt symptoms can be used as a strategy to slow disease progress $(40,46)$. However, in Brazil, mango cultivars with high levels of resistance to mango wilt are the most effective strategy adopted by farmers to control the disease $(12,40,41,46)$. Resistance is critical because mango wilt cannot be controlled by fungicides $(12,40,41,46)$. The high degree of genetic variability in aggressiveness of $C$. fimbriata renders resistant mango cultivars to become susceptible in a relatively short time $(40,41,46)$.

Corresponding author: F. A. Rodrigues; E-mail address: fabricio@ufv.br

* The $e$-Xtra logo stands for "electronic extra" and indicates that Figures 1 to 5 appear in color online.

http://dx.doi.org/10.1094/PHYTO-11-13-0316-R

(C) 2014 The American Phytopathological Society
The resistance of trees to vascular pathogens is primarily based on their ability to restrict pathogen infection to a few cells (20). Suberized bark containing phenolic-like compounds, the composition of the xylem vessels, and their diameter are common examples of preformed mechanisms that restrict infection by vascular pathogens $(6,20,32)$. In contrast, active defense mechanisms include anatomical responses such as deposition of gels and the formation of tyloses in invaded vascular vessels $(9,20)$. The formation of barrier zones; intense lignification and suberization of cell walls; and the production of phenolics, phytoalexins, and proteins related to pathogenesis are also involved in active defenses $(9,20,43)$.

Pre- or post-infection phenolics play a pivotal role in the host defense against pathogenic infection (34), primarily because of their effect on cell wall lignification (5), antimicrobial activity (45), modulation of plant hormones involved in defense signaling pathways, and the scavenging of reactive oxygen species (19). Suberin, phytoalexins, phenolics, and lignin are the major components in barrier zones formed in host tissue in response to pathogen infection $(9,11,43,49,53)$.

Important insights into specific responses in infected tissue to pathogen infection can be obtained by examining autofluorescence $(2,9,21,29,43)$. Autofluorescence can be used because phenolics and related polymers such as lignin absorb shortwavelength light, in ultraviolet (UV) and near-blue range, and emit longer wavelengths of visible light $(2,9,21,29,43)$. Thus, microscopes capable of producing UV and near-blue light for excitation of phenolics and fitted with the proper filters will readily reveal localized autofluorescent compounds in tissue $(2,9,21,29,43)$. For example, stem sections from balsam poplar infected by Ophiostoma novo-ulmi when observed under UV light excitation showed stronger autofluorescence in cellular barrier zones (43). Intense autofluorescence was also produced by 
suberin and lignin in callus cultures of American elm infected by O. novo-ulmi (2). Eynck et al. (21) observed intense deposition of phenolics and lignin compounds in the roots and hypocotyls of plants from a resistant cultivar of oilseed rape in response to infection by Verticillium longisporum when compared with tissue from plants of a susceptible cultivar. The resistant cultivar exhibited a much stronger autofluorescence when excited by light in the near-UV range than the susceptible cultivar (21).

The concentration of certain chemical elements in plant tissue also can affect their resistance to vascular pathogens (17). High levels of sulfur in stem tissue of cacao (14) and tomato (57) plants were associated with increased resistance to infection by $V$. dahliae. Sulfur and sulfur compounds also decrease disease directly as a result of antimicrobial activities and indirectly by enhancing host resistance (27). Increased calcium content in plant tissue also correlates with the resistance of cell walls and the middle lamella to fungal pathogen invasion $(3,13,39)$. Calcium also acts as a signal for oxidative bursts that trigger the synthesis of phytoalexins and the induction of defense-related genes whose products lead to resistance in many host-pathogen interactions $(30,39)$.

The presence of amorphous material is a typical feature of active plant cell defense against infection by pathogenic fungi $(4,5,21,26,45)$. Amorphous material is frequently associated with phenolic-like compounds because of its texture, osmiophilic properties (47), and ability to alter fungal hyphae $(7,8,35,44,45)$. According to Hall et al. (26), accumulation of amorphous materials identified as terpenoid phytoalexins in the xylem vessels and adjacent parenchyma cells in the roots of a resistant cotton cultivar restricted the colonization of Fusarium oxysporum f. sp. vasinfectum.

The objectives of the current study were to describe and characterize host responses to C. fimbriata in stems of resistant and susceptible mango cultivars with a view of discovering more effective ways to control mango wilt. To achieve these objectives, an infection time course in two mango cultivars, 'Ubá' (resistant) and 'Haden' (susceptible), was employed. Both fluorescence light microscopy and transmission and scanning electron microscopy (TEM and SEM, respectively) coupled with energy dispersive $\mathrm{X}$-ray microanalysis were used to help describe and characterize cellular responses in stem tissue of the two cultivars.

\section{MATERIALS AND METHODS}

Plant material. Haden (susceptible) and Ubá (resistant) mango plants were obtained from a commercial nursery (Dona Euzébia city, Minas Gerais State, Brazil) and their rootstock was from 'Imbú'. The 1.5-year-old plants were transplanted into plastic pots containing $8 \mathrm{~kg}$ of soil, sand, and manure in a $2: 1: 1$ proportion. Plants were kept in a greenhouse (temperature of $30 \pm 2{ }^{\circ} \mathrm{C}$ during the day and $10^{\circ} \mathrm{C}$ at night and relative humidity of $70 \pm 5 \%$ ) for 2 months before starting the experiments.

Inoculation procedure. The isolate MSAK16 of $C$. fimbriata used to inoculate the plants was obtained from symptomatic mango plants collected in Aquidauana, Mato Grosso do Sul State, Brazil. The isolate was preserved using Castellani's method (18). Plugs of a malt extract agar medium containing fungal mycelia were transferred to petri dishes containing potato dextrose agar (PDA). After 3 days, the PDA plugs containing fungal mycelia were transferred to petri dishes containing the same culture medium and maintained in an incubator (temperature of $25^{\circ} \mathrm{C}$ and a 12-h photoperiod) for 14 days.

Inoculation was performed following the methods of Al-Sadi et al. (1). Bark disks (10 $\mathrm{mm}$ in diameter and $2 \mathrm{~mm}$ in height) were removed from the stems of both cultivars using a punch. The disks came from $\approx 5 \mathrm{~cm}$ above the graft scar. A plug $(10 \mathrm{~mm}$ in diameter) removed from the middle portion of each PDA plate obtained from 14-day-old colonies of C. fimbriata was placed in the wound. Each wound containing the fungal mycelia PDA plug was carefully covered with a piece of moistened cotton and enclosed with parafilm to maintain adequate moisture to promote fungal infection. Wounds only receiving plugs of PDA medium served as the control.

Disease assessment. Disease progress in stem tissue and development of wilted leaves was evaluated at 15, 22, and 29 days after inoculation (dai). The upward, downward, and radial colonization of the stem tissue by the hyphae of $C$. fimbriata was accomplished by measuring the length (in centimeters) of internal necrotic tissue using an electronic digital caliper (Neiko 01407A; Stainless Steel, Mandaluyong, Philippines). Upward relative lesion length (URLL) and downward relative lesion length (DRLL) were expressed as the ratio between the length from the graft scar to the top of the stem (LGST) and the lesion length (LL) taken from the same area (upward and downward) beginning at the inoculation point. The formula URLL or DRLL $=\mathrm{LL} \times$ 100/LGST was used. The stem of each plant was standardized to a length of $20 \mathrm{~cm}$ (distance from the graft scar to the top of the stem). The radial fungal colonization (RFC) was determined as the length of the necrotic tissue in relation to the total stem diameter $\times 100$. Symptoms of internal necrotic tissue in both longitudinal and transverse stem sections inoculated with $C$. fimbriata were photographed at $\times 6.5$ for whole stem tissue and $\times 40$ for stem tissue-associated perithecia. This was done using a stereomicroscope (Stemi 2000-C; Carl Zeiss, Jena, Thuringia, Germany) coupled to a digital camera (Canon PowerShot A640, Canon Inc., Tokyo, Japan).

The percentage of wilted leaves from the total number of leaves per plant of each cultivar was determined using the methods of Al-Sadi et al. (1). Representative mango plants infected with $C$. fimbriata were digitally photographed (Coolpix L110; Nikon, Tokyo, Japan) at each sampling time to record the pattern of wilting development.

Data from URLL, DRLL, RFC, and the percentage of wilted leaves were used to calculate the area under the upward relative lesion length progress curve (AUURLLPC), the area under the downward relative lesion length progress curve (AUDRLLPC), the area under the radial fungal colonization progress curve (AURFCPC), and the area under the wilted leaves progress curve (AUWLPC), respectively, according to the method of Shaner and Finney (48).

Processing the infected stem tissue for microscopic studies. In total, 25 to 30 transverse and longitudinal stem sections from four plants of the two cultivars ( $10 \mathrm{~mm}$ thick) were obtained from $3 \mathrm{~cm}$ below and above the inoculation point at 15, 22, and 29 dai. Stem sections of noninoculated plants served as comparative controls. Stem sections were carefully transferred to glass vials containing $10 \mathrm{ml}$ of fixative composed of $3 \%$ (vol/vol) glutaraldehyde and $2 \%$ (vol/vol) paraformaldehyde in $0.1 \mathrm{M}$ sodium cacodylate buffer ( $\mathrm{pH} 7.2)$. Vials were then covered in aluminum foil and stored at $4{ }^{\circ} \mathrm{C}$ for 2 months (45) until used for microscopic studies.

Fluorescence microscopy. In total, four transverse and longitudinal stem sections from inoculated plants of Haden and Ubá were carefully washed three times with distilled water and mounted on glass slides with two drops of a glycerine/water solution (2:8, $\mathrm{vol} / \mathrm{vol}$ ) according to the basic methodology of Eynck et al. (21) and Koga et al. (29). Stem sections from noninoculated plants of the two cultivars served as the control treatment.

Autofluorescence of stem sections was achieved using an fluorescent Carl Zeiss Axio Imager A1 microscope (Carl Zeiss, Jena, Thuringia, Germany) with Zeiss filter sets 01 (UV; $365 \mathrm{~nm}$ excitation, $395 \mathrm{~nm}$ beam splitter, and $397 \mathrm{~nm}$ emission) and 05 (blue; 395 to $400 \mathrm{~nm}$ excitation, $460 \mathrm{~nm}$ beam splitter, and $470 \mathrm{~nm}$ emission). Images were acquired digitally (Axio Cam HR; Carl Zeiss, Jena, Thuringia, Germany) and further processed with Axion Vision 4.8.1 software. 
X-ray microanalysis. Insoluble elemental composition and relative levels in transverse stem tissue of Haden and Ubá collected at 22 and 29 dai were investigated by energy dispersive X-ray spectroscopy (EDS) using a scanning electron microscope (LEO 1430VP; Carl Zeiss, Oberkochen, Germany) with an attached X-ray detector system (Tracor TN5502, Middleton, WI). Samples were dehydrated in ethanol, submitted to critical point drying in $\mathrm{CO}_{2}$ (Bal-tec, model CPD 030; Electron Microscopy Sciences [EMS], Hatfield, PA). Specimens were mounted onto aluminum stubs (two specimens from each sample) and coated with a thin film of evaporated carbon (Quorum Q150 T, East Grinstead, West Sussex, England, UK). Because soluble (diffusible) elements are lost during liquid ethanol dehydration and substitution with liquid $\mathrm{CO}_{2}$, the remaining element should be considered largely bound to cell components and, therefore, insoluble (58).

The EDS microanalysis on all specimens was performed at magnifications of $\times 40$ and 1000 with an accelerating voltage of $20 \mathrm{kV}$ and a working distance of $19 \mathrm{~mm}$. For each treatment, a total area of $18 \times 10^{7} \mu \mathrm{m}^{2}$ was analyzed in each sample of stem tissue. The distribution patterns of calcium $(\mathrm{Ca})$, iron $(\mathrm{Fe})$, magnesium $(\mathrm{Mg})$, manganese $(\mathrm{Mn})$, potassium $(\mathrm{K})$, and sulfur $(\mathrm{S})$ were based on secondary electron images, X-ray emission spectra, and corresponding X-ray elemental maps according to the methods of Goldstein et al. (24) and Williams et al. (57). In total, 10 images were obtained from each sample of stem tissue per treatment.

SEM. Transverse and longitudinal stem tissue from Haden and Ubá were collected at 22 and 29 dai, washed with sodium cacodylate buffer $(0.1 \mathrm{M})$, and postfixed for $1 \mathrm{~h}$ at room temperature with $1 \%(\mathrm{wt} / \mathrm{vol})$ osmium tetroxide prepared in the same buffer. Samples were dehydrated and mounted on aluminum stubs and sputter coated with gold (Balzers Union, model FDU 010; EMS, Hatfield, PA). A LEO scanning electron microscope operating at $10 \mathrm{Kv}$, with a working distance of 10 to $30 \mathrm{~mm}(24,51)$, was used to obtain photomicrographs. For each treatment, two stubs with two samples of stem tissue were examined by SEM.

TEM. Transverse and longitudinal stem tissue were collected at 22 dai and washed and postfixed with 1\% (wt/vol) osmium tetroxide. Samples were then dehydrated and embedded in Spurr's resin (EMS) in a 25 and $33 \%$ gradient for $1 \mathrm{~h}, 66$ and $75 \%$ gradient for $12 \mathrm{~h}$, and $100 \%$ resin for $36 \mathrm{~h}$. Because of their extreme sample hardness, they were placed in a vacuum chamber for $3 \mathrm{~min}$ at each gradient to allow better resin infiltration. The samples were mounted in flat embedding molds, embedded in pure Spurr's resin, and polymerized in an oven at $65^{\circ} \mathrm{C}$ for $24 \mathrm{~h}$. Thick sections $(0.5 \mu \mathrm{m})$ were cut from the embedded material with glass knives using a Leica RM 2245 rotary microtome (Leica Microsystems, Nussloch, Germany). Sections were stained with $1 \%$ toluidine blue in $2 \%$ sodium borate for $5 \mathrm{~min}$ for light microscope observations. Once infection threads were located under the light microscope, ultrathin sections $(70 \mathrm{~nm})$ were taken from the embedded material using a diamond knife (Diatome, Hatfield, PA) using a Power Tome-X ultramicrotome (RMC,

TABLE 1. Area under upward relative lesion length progress curve (AUURLLPC), area under downward relative lesion length progress curve (AUDRLLPC), area under radial fungal colonization progress curve (AURFCPC), and area under wilted leaf progress curve (AUWLPC) for plants from 'Haden' (susceptible) and 'Ubá' (resistant) mango inoculated with Ceratocystis fimbriata

\begin{tabular}{lcccc}
\hline & \multicolumn{4}{c}{ Variables $^{\mathrm{a}}$} \\
\cline { 2 - 5 } Cultivars & AUURLLPC & AUDRLLPC & AURFCPC & AUWLPC \\
\hline Haden & 592.4 & 183.4 & 974.4 & 340.2 \\
Ubá & 104.7 & 107.4 & 394.6 & 0.0 \\
$F$ values & $0.008^{* *}$ & $0.029 *$ & $0.000 * *$ & $0.000 * *$ \\
\hline
\end{tabular}

a Asterisks $*$ and $* *=$ significant at 5 and $1 \%$ of probability, respectively.
Boeckeler Instruments, Tucson, AZ). Ultrathin sections were mounted on copper grids (200-mesh square), stained with $2 \%$ uranyl acetate and $1 \%$ lead acetate for 20 min each and examined by TEM (Zeiss EM 109; Carl-Zeiss, Oberkochen, Germany) operating at $80 \mathrm{Kv}$, according to the methods of Bozzola and Russel (10) and Rodrigues et al. (45). For each treatment, four blocks were carefully selected for cutting and, from each block, 10 thick and 8 to 16 ultrathin sections were examined under the light and transmission electron microscopes, respectively.

Experimental design and data analysis. For comparison of the two mango cultivars, a completely randomized design with four replications was used. Each replication consisted of a plastic plot containing one mango plant. The experiment was repeated once. Data from AUURLLPC, AUDRLLPC, AURFCPC, and AUWLPC were analyzed with analysis of variance and the treatment means compared by an $F$ test $(P \leq 0.05)$ using SAS (release 8.02, level 02M0 for Windows; SAS Institute, Inc., Cary, NC).

\section{RESULTS}

Disease assessment. The AUURLLPC, AUDRLLPC, AURFCPC, and AUWLPC were significantly higher for the susceptible Haden when compared with the resistant Ubá (Table 1). Plants from Haden started to wilt at 13 dai, whereas plants from Ubá did not wilt until the end of the experiments (Fig. 1). Stem tissue obtained from Haden had more internal necrosis than did the stem tissue of Ubá (Figs. 1, 2C to $\mathrm{H}$, and $3 \mathrm{C}$ to $\mathrm{H}$ ).

Fluorescence microscopy. Stem sections from noninoculated plants of each cultivar did not show autofluorescence (Figs. 2A1, A2, B1, and B2; and 3A1, A2, B1, and B2). In Ubá at 15, 22, and 29 dai, tissue proximal to the internal necrotic areas, such as cortical parenchyma, xylem vessels, parenchyma cells, and pith parenchyma in the stem sections, exhibited strong autofluorescence using blue and UV light filter sets (Figs. 2D1, D2, F1, F2, $\mathrm{H} 1$, and $\mathrm{H} 2$; and 3D1, D2, F1, F2, H1, and H2). At the same evaluation times, the stem tissue of inoculated plants from Haden exhibited weak autofluorescence (Figs. 2C1, C2, E1, E2, G1, and $\mathrm{G} 2$; and 3C1, C2, E1, E2, G1, and G2).

X-ray microanalysis. The stem tissues from Haden and Ubá were colonized by $C$. fimbriata (Fig. 4 A to D). At 22 dai, the peaks for insoluble $S$ and $\mathrm{Ca}$ in Ubá stem tissue were $\approx 15$ and $30 \%$ higher when compared with the Haden (Fig. 4A1 and B1). At 29 dai, the peaks for $\mathrm{S}$ and $\mathrm{Ca}$ in the Ubá stem tissue were greater by $\approx 17$ and $72 \%$, respectively, when compared with the Haden (Fig. 4C1 and D1). For all evaluation times, higher levels of deposition of $\mathrm{S}$ and $\mathrm{Ca}$ in the Ubá stem tissue were observed proximal to the inoculation point compared with the Haden (Fig. 4A2, A3, B2, B3, C2, C3, D2, and D3). At 22 dai, abundant amounts of fungal hyphae and chlamydospores (aleurioconidia) of $C$. fimbriata were visible in parenchyma cells of the stem tissue of both cultivars but, in Haden stem tissue, fungal hyphae had reached xylem vessels (Fig. 5A and B). The S and Ca peaks detected in the Ubá stem tissue, which was densely colonized by C. fimbriata, were higher by $\approx 108$ and $281 \%$, respectively, compared with Haden (Fig. 5A1 and B1). At 29 dai, xylem vessels were obstructed by the formation of tyloses in both Haden and Ubá (Fig. 5C and D). The S and Ca peaks from xylem vessels containing tyloses in the Ubá stem tissue were higher by $\approx 93$ and $255 \%$, respectively, than those in the Haden (Fig. 5C1 and D1). Thus, at all evaluation times, levels of insoluble $\mathrm{S}$ and $\mathrm{Ca}$ deposition were higher in the cells colonized by $C$. fimbriata and in xylem vessels containing tyloses in the Ubá stem tissue in comparison with Haden (Fig. 5A2, A3, B2, B3, C2, C3, D2, and D3).

SEM. At 22 dai, chlamydospores had formed or were in the process of formation in cortical parenchyma of the stem tissue from both cultivars (Fig. 6A, A1, G, and G1). In the Haden stem 
tissue, long fungal hyphae invaded xylem vessels, stimulating formation of a substantial amount of polysaccharide gel and tyloses (Fig. 6B to E). In the Ubá stem tissue, numerous chlamydospores were observed in parenchyma cells and xylem vessels (Fig. 6H to L). In xylem vessels of Ubá stem tissue, polysaccharide gels were infrequent (Fig. $6 \mathrm{H}$ to L). Fungal hyphae extensively colonized the pith parenchyma of Haden stem tissue (Fig. 6F) but were not observed in these same cells of Ubá (Fig. $6 \mathrm{G}$ to L). At 29 dai, several fungal hyphae, chlamydospores, and perithecia-like structures were visible on the Haden stem tissue. These started from the stem region where inoculation occurred and progressed toward the cortical parenchyma and xylem vessels distal to the inoculation area (Fig. 7A, A1, B, C, C1, D, and E). By comparison, on Ubá, the fungal structures were only observed in the cortical parenchyma and xylem vessels proximal to the inoculation area (Fig. 7G, H, H1, I, I1, J, J1, K, and L). Fungal hyphae extensively colonized the pith parenchyma of Haden (Fig. 7F), but were not observed in these same cells of Ubá (Fig. 7G to L).

TEM. Fungal hyphae easily invaded fiber and parenchyma cells adjacent to xylem vessels in the stem tissue of Haden (Fig. $8 \mathrm{~A}$ to E). In Ubá, fungal hyphae were often surrounded by dense amorphous granular material in fiber and parenchyma cells (Fig. 9A to D). Parenchyma cell walls in Haden showed signs of intense degradation after colonization by C. fimbriata (Fig. $8 \mathrm{~B}$ to E). In contrast, the parenchyma cell walls of Ubá rarely were degraded and were encrusted by amorphous granular material (Fig. 9A to D). Long and thick fungal hyphae were often found in Haden stem tissue (Fig. 8) but were thin and faint and sometimes appeared dead in Ubá (Fig. 9). Fungal hyphae penetrated pit membranes and reached the xylem vessels in Haden (Fig. 8F and G) whereas, in Ubá, fungal colonization was impeded by the deposition of amorphous granular material (Fig. 9E and F).
Fungal hyphae that reached xylem vessels in Ubá stem tissue were often surrounded by dense amorphous granular material and some appeared dead (Fig. 9E and G). In contrast, fungal hyphae abundantly colonized the xylem vessels in Haden stem tissue (Fig. 8F and G).

\section{DISCUSSION}

This study provides direct evidence for differences in response to infection by $C$. fimbriata at the cellular level in two mango cultivars. Responses of Haden and Ubá to $C$. fimbriata infection were as a susceptible and resistant reaction, respectively, when inoculated and kept at greenhouse conditions. This reaction mirrored what has been observed in their performance under production field practices $(40,46,56)$.

Tissue proximal to the internal necrotic areas in the stem sections obtained from Ubá had stronger autofluorescence compared with Haden. There are several published reports of autofluorescence around necrotic areas in the stem tissue of resistant plants attacked by vascular pathogens $(2,7,9,21,43)$. In these reports, resistance is manifested by barrier zones that reduce the spread of the pathogens $(2,7,9,21,43)$. Suberin, lignin, and phenolic-like compounds are of great importance in barrier zones, as demonstrated in the interactions between American elm and O. novo-ulmi (2), white fir and Phellinus pini (9), trembling aspen and Entoleuca mammata (11), oilseed rape and $V$. longisporum (21), balsam poplar and O. novo-ulmi (43), jack pine and Gremmeniella abietina (49), and sugar maple and C. coerulescens (53). Phenolic-like compounds, phytoalexins, suberin, and lignin will autofluorescence when excited by near blue and UV light $(2,7,9,21,29,43)$. Bishop and Cooper (7) observed strong autofluorescence of pea stem tissue from the accumulation of
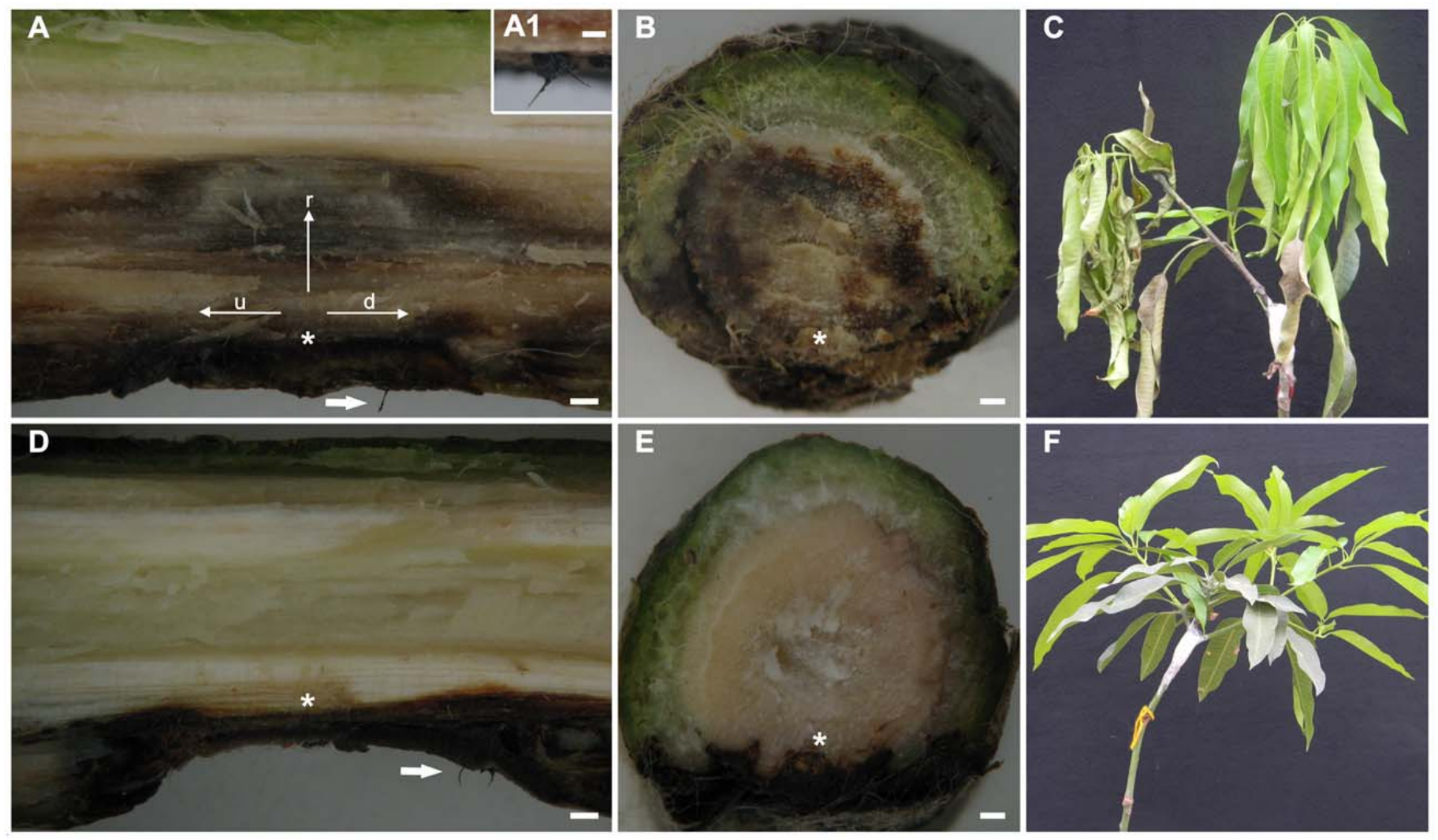

Fig. 1. Internal necrotic tissue caused by Ceratocystis fimbriata infection in $\mathbf{A}$ and $\mathbf{D}$, longitudinal and $\mathbf{B}$ and $\mathbf{E}$, transverse stem sections and $\mathbf{A}$ and $\mathbf{F}$, wilting symptoms in mango plants from the $\mathbf{A}$ to $\mathbf{C}$, susceptible Haden and $\mathbf{D}$ to $\mathbf{F}$, resistant Ubá at 22 days after inoculation. Asterisks $(*)$ indicate the stem region where the fungal inoculation occurred and from which the upward (u), downward (d), and radial (r) C. fimbriata colonization were observed, as detailed in A. The formation of perithecia of $C$. fimbriata was observed at the inoculation point (arrow in A and C). In A1, perithecia of $C$. fimbriata are shown at a higher magnification. Scale bars: $1000 \mu \mathrm{m}$ (A, B, D and E) and $500 \mu \mathrm{m}(\mathrm{A} 1)$. 

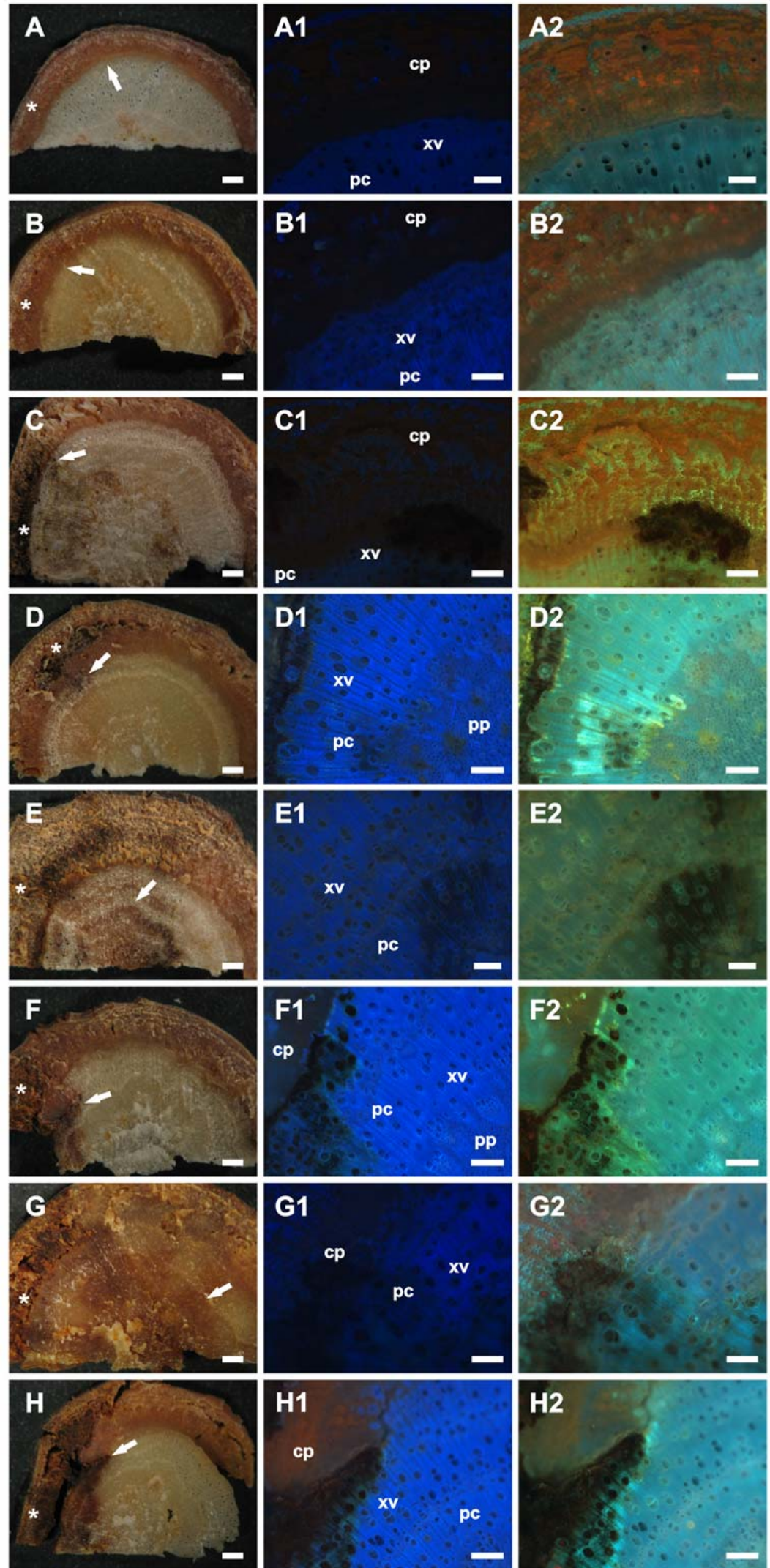

Fig. 2. Stem sections of noninoculated plants of A, A1, and A2, Haden and B, B1, and B2, Ubá. C to $\mathbf{H}$, Symptoms of internal necrotic tissue and fluorescence microscopy images in transverse stem sections from mango plants of C1, C2, E1, E2, G1, and G2, Haden and D1, D2, F1, F2, H1, and H2, Ubá at 15 (C, C1, C2, D, D1, and D2), 22 (E, E1, E2, F, F1, and F2), and 29 (G, G1, G2, H, H1, and H2) days after inoculation (dai) with Ceratocystis fimbriata. Asterisks (*) in A to $\mathrm{H}$ indicate the stem region where the wound for fungal inoculation was made. Arrows indicate the stem region where autofluorescence in noninoculated (A, A1, A2, B, B1, and B2) and inoculated (C, C1, C2, D, D1, D2, E, E1, E2, F, F1, F2, G, G1, G2, H, H1, and H2) plants was recorded when observed with blue (395 to $400 \mathrm{~nm}$ excitation) and UV light (365 nm excitation) filter sets. Cortical parenchyma (cp), parenchyma cells (pc), pith parenchyma (pp), and xylem vessels (xv). Scale bars: A to $\mathrm{H}=1000 \mu \mathrm{m}$ and A1, A2, B1, B2, C1, C2, D1, D2, E1, E2, F1, F2, G1, G2, H1, and H2 = $250 \mu \mathrm{m}$. 

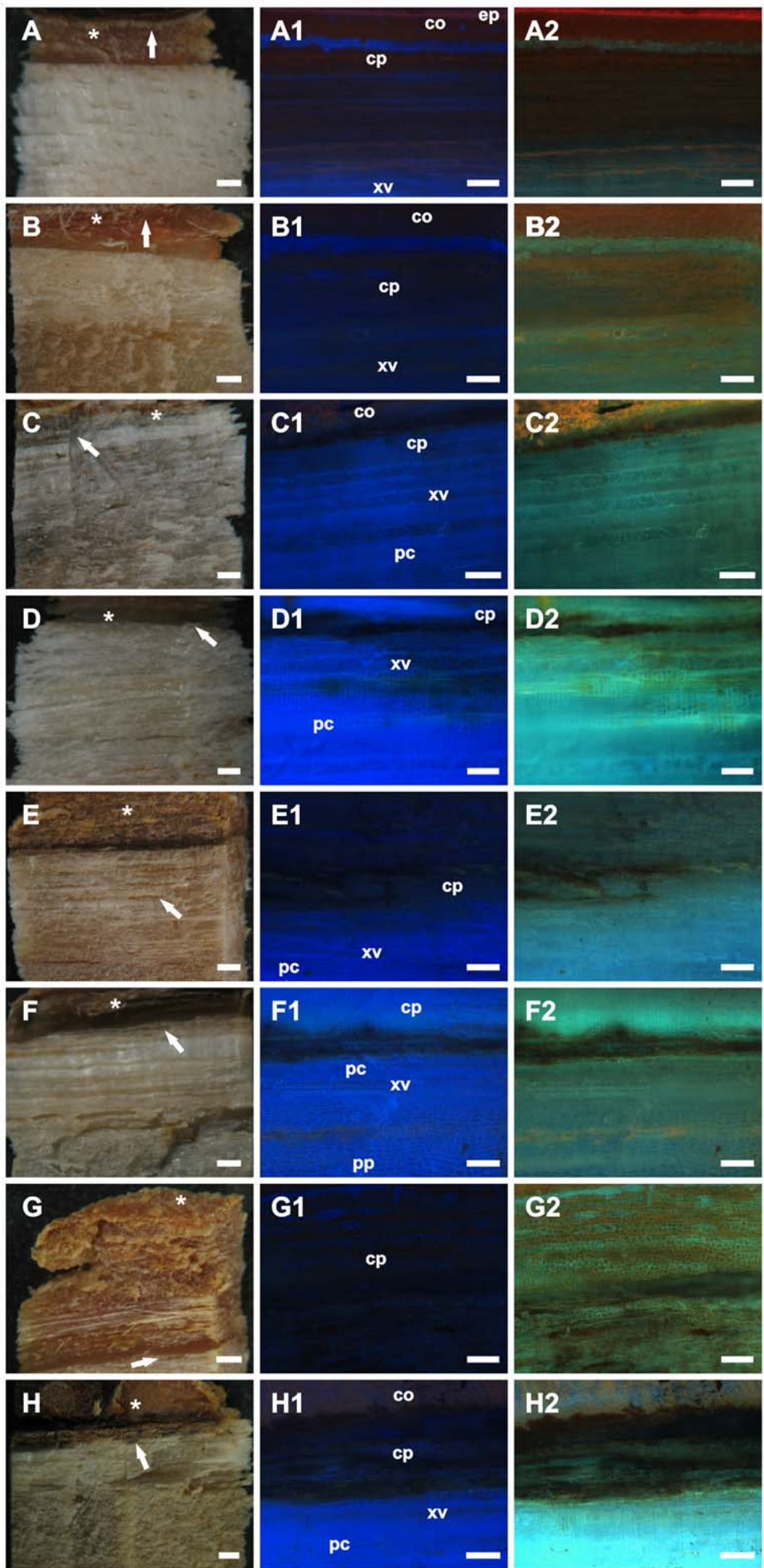

Fig. 3. Stem sections of noninoculated plants of A, A1, and A2, Haden and B, B1, and B2, Ubá. C to $\mathbf{H}$, Symptoms of internal necrotic tissue and fluorescence microscopy images in longitudinal stem sections from mango plants of C1, C2, E1, E2, G1, and G2, Haden and D1, D2, F1, F2, H1, and H2, Ubá at 15 (C, C1, C2, D, D1, and D2), 22 (E, E1, E2, F, F1, and F2), and 29 (G, G1, G2, H, H1, and H2) days after inoculation (dai) with Ceratocystis fimbriata. Asterisks (*) in A to $\mathrm{H}$ indicate the stem region where the wound for fungal inoculation was made. Arrows indicate the stem region where autofluorescence in noninoculated (A, A1, A2, B, B1, and B2) and inoculated (C, C1, C2, D, D1, D2, E, E1, E2, F, F1, F2, G, G1, G2, H, H1, and H2) plants was recorded when observed with blue (395 to $400 \mathrm{~nm}$ excitation) and UV light (365 nm excitation) filter sets. Collenchyma (co), cortical parenchyma (cp), epidermis (ep), parenchyma cells (pc), pith parenchyma (pp), and xylem vessels (xv). Scale bars: A to H = $1000 \mu \mathrm{m}$ and A1, A2, B1, B2, C1, C2, D1, D2, E1, E2, F1, F2, G1, G2, H1, and H2 = 250 $\mu \mathrm{m}$. 
phenolics as a result of a hypersensitive reaction in response to the $F$. oxysporum f. sp. pisi attack. In the present study, the strong autofluorescence around the necrotic stem tissue obtained from Ubá in response to $C$. fimbriata infection is most likely due to of barrier zones infused with suberin, lignin, and phenolic-like compounds. These compounds help prevent the spread of the fungus through the vascular system.

The peaks and deposition of bound or insoluble $\mathrm{S}$ and $\mathrm{Ca}$ in the stem tissue from Ubá attacked by $C$. fimbriata were always higher than those produced by tissue from Haden. It is known that higher levels of the chemical elements $\mathrm{S}$ and $\mathrm{Ca}$ in plant tissue can increase resistance to vascular pathogens (17). Cooper et al. (14) reported the presence of two phenolics, a triterpenoid and an elemental S, as cyclooctasulfur in the xylem vessels of the stem tissue of a resistant genotype of cacao in response to infection by $V$. dahliae. X-ray microanalysis also revealed a higher accumulation of $S$ in the cells that were in close contact with hyphae of
V. dahlia (14). Sugimoto et al. (52) found that soybean plants supplied with a high level of $\mathrm{Ca}$ showed reduced symptoms of Phytophthora stem rot. X-ray microanalysis also showed that $\mathrm{Ca}$ crystals were found around the cambium and xylem in the stem tissue of soybean, suggesting the importance of $\mathrm{Ca}$ ion storage in maintaining long-term field resistance and reducing Phytophthora sojae penetration (52). In the present study, high levels of $\mathrm{S}$ in the stem tissue of Ubá were associated with putative antimicrobial activity against $C$. fimbriata, suggesting a novel mechanism of defense for the interaction between mango plants and $C$. fimbriata. The high levels of $\mathrm{Ca}$ in the stem tissue from Ubá may also have contributed to the strength of the cell walls, which hampered $C$. fimbriata colonization.

Long fungal hyphae, chlamydospores, and perithecia-like structures of $C$. fimbriata were found in abundance in stem tissue of the susceptible Haden based on SEM observations. The same $C$. fimbriata structures were less apparent in resistant Ubá. The
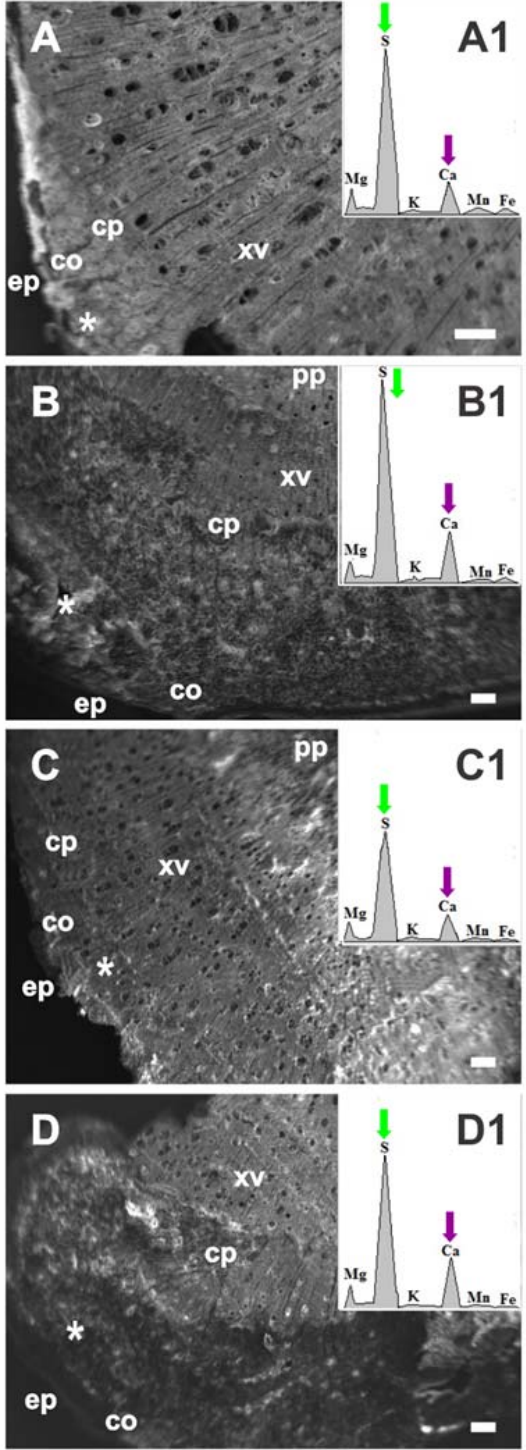
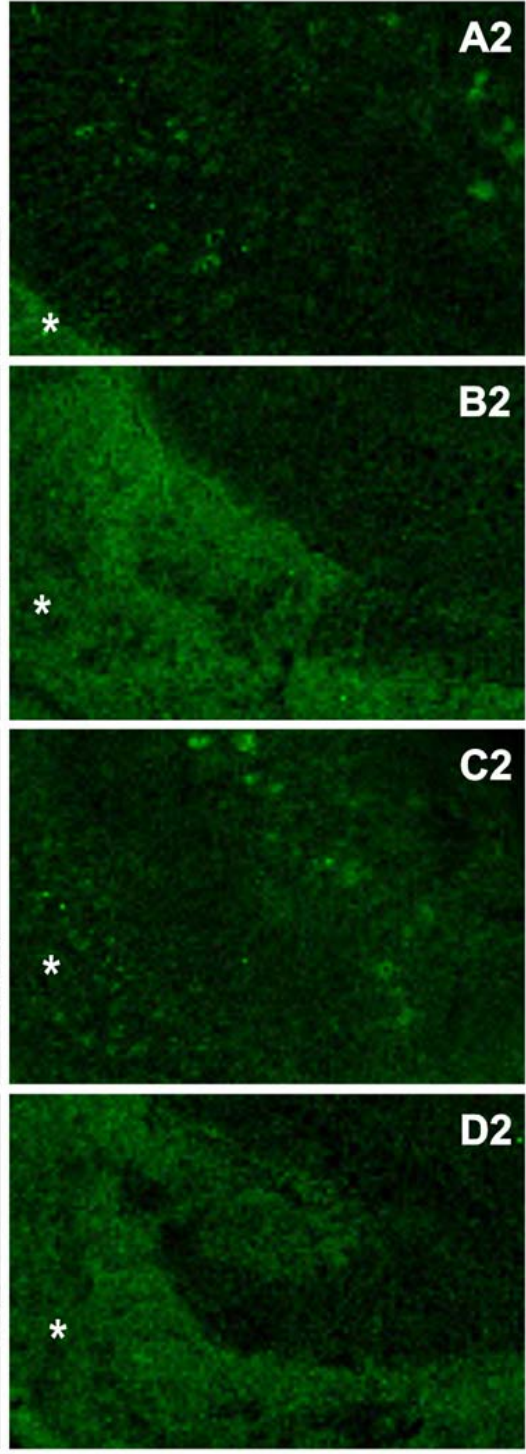
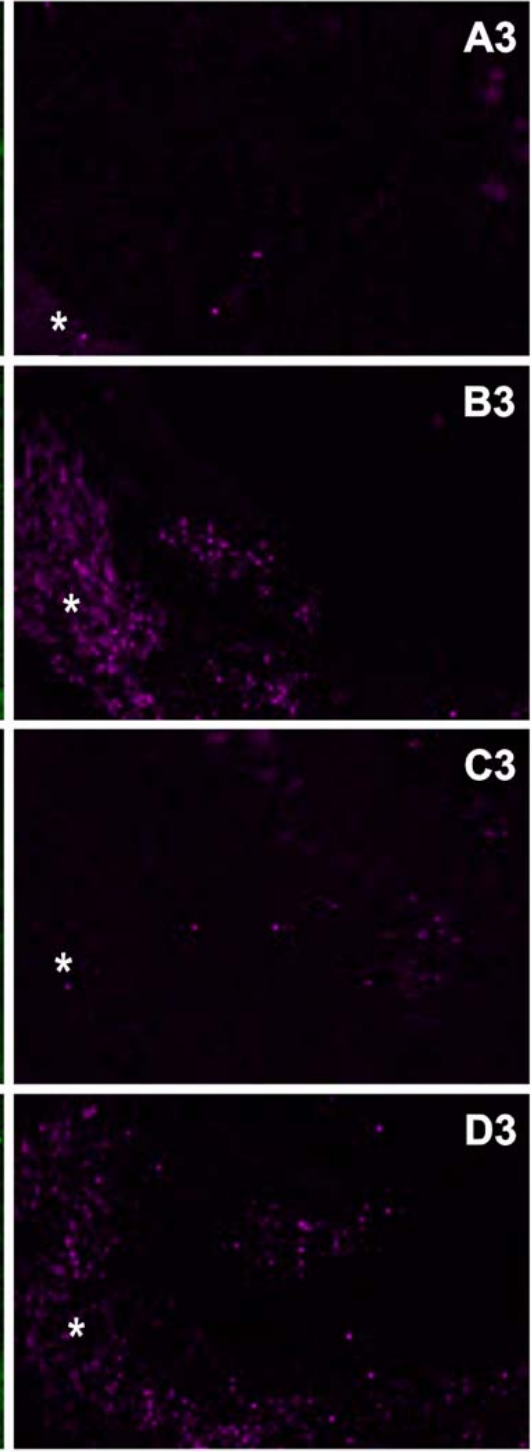

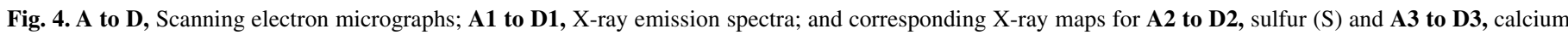

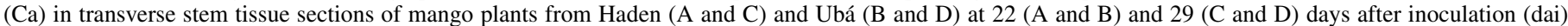

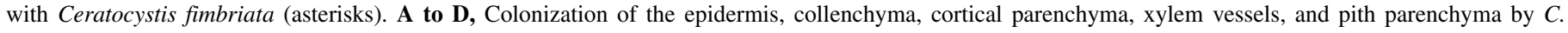

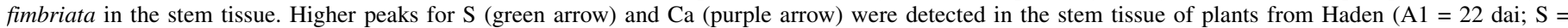

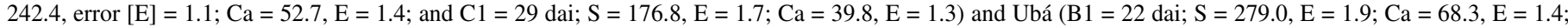

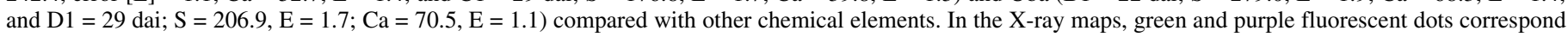

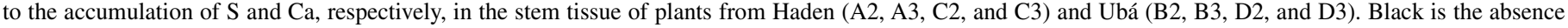

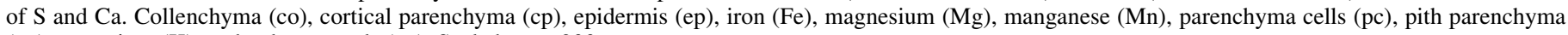
(pp), potassium (K), and xylem vessels (xv). Scale bars $=200 \mu \mathrm{m}$. 
colonization of stem tissue of susceptible cultivars by vascular pathogens is enhanced and their xylem vessels are often obstructed by fungal hyphae and polysaccharide gels and the formation of tyloses $(7,8,15,37,44)$. The resistance of trees to vascular pathogens results from their ability to restrict pathogens to a few cells (20) based on pre- or post-formed defense mechanisms $(6,9,20,32,43)$. In the present study, the intense autofluorescence, stronger peaks, and depositions of elemental S and Ca near inoculation areas in the stem tissue of Ubá appear to act as a barrier preventing radial spread of hyphae from reaching the pit parenchyma.

TEM revealed long, thickened fungal hyphae in fiber and parenchyma cells as well as in the xylem vessels of Haden. However, in Ubá, hyphae were thin and faint in these same cells and were often surrounded or trapped in dense amorphous granular material, and often hyphae appeared to be dead. The presence of amorphous material, frequently reported to consist of phenoliclike compounds, is a typical feature of cellular defense used by many plant species to cope with fungal infection $(4,5,7,8,21$, $26,35,45)$. Others have reported the occurrence of dead hyphae surrounded or trapped in amorphous material $(4,5,7,8,35,38,45)$. This phenomena is found in numerous plant species $(4,5,7,8$, $35,38,45)$. The fungitoxic effect of most phenolics is attributed to their interaction with lipids or phospholipids, which increases fungal membrane permeability, leakage of hyphal contents, and cytoplasm aggregation (50). In mango fruit, many antimicrobial phenolic compounds such as catechin, coumaric acid, gallic acid, hydroxybenzoic acid, isomangiferin, kaempferol, mangiferin, protocatechuic acid, quercetin, sinapic acid, and shikimic acid have been reported $(31,42)$. Therefore, the reduced fungal colonization of the stem tissue in Ubá was most likely due to the intense accumulation of phenolic-like compounds surrounding the fungal hyphae and resulting in stronger autofluorescence and greater $\mathrm{S}$ deposition in close proximity to these hyphae.

The parenchyma cell walls of the Haden colonized by fungal hyphae often showed strong signs of degradation. In contrast, the
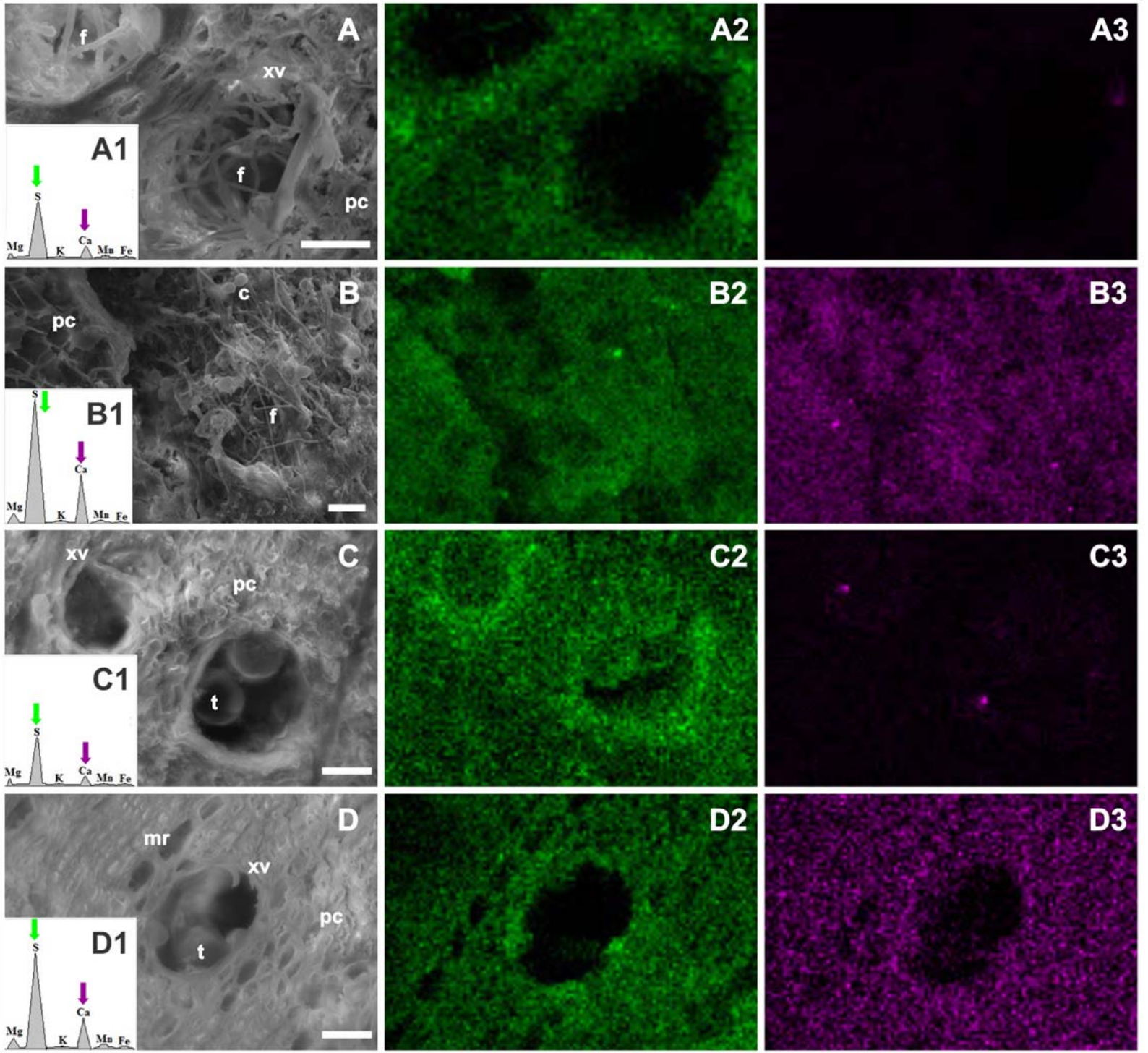

Fig. 5. A to D, Scanning electron micrographs; A1 to D1, X-ray emission spectra; and corresponding X-ray maps for A2 to D2, sulfur (S) and A3 to D3, calcium (Ca) in transverse stem tissue sections of mango plants from Haden (A and C) and Ubá (B and D) at 22 (A and B) and 29 (C and D) days after inoculation (dai) with Ceratocystis fimbriata. A, Hyphae of $C$. fimbriata extensively colonized the xylem vessels. B, Fungal hyphae grew abundantly in the parenchyma cells. C and D, Xylem vessels in the stem tissue of plants from Haden and Ubá were obstructed by the formation of tyloses at 29 dai. Higher peaks of S (green arrow) and $\mathrm{Ca}$ (purple arrow) were detected in the stem tissue of Haden $(\mathrm{A} 1=22$ dai; $\mathrm{S}=120.3$, error $[\mathrm{E}]=1.2 ; \mathrm{Ca}=25.2, \mathrm{E}=0.8 ;$ and $\mathrm{C} 1=29$ dai; $\mathrm{S}=89.2, \mathrm{E}=1.1 ; \mathrm{Ca}=$ $16.8, \mathrm{E}=0.8)$ and Ubá $(\mathrm{B} 1=22$ dai; $\mathrm{S}=250.8, \mathrm{E}=1.8 ; \mathrm{Ca}=96.1, \mathrm{E}=1.3 ;$ and $\mathrm{D} 1=29$ dai; $\mathrm{S}=171.7, \mathrm{E}=1.6 ; \mathrm{Ca}=59.7, \mathrm{E}=1.1)$ compared with other chemical elements. In the X-ray maps, green and purple fluorescent dots correspond to the accumulation of $\mathrm{S}$ and Ca, respectively, in the stem tissue of plants from Haden (A2, A3, C2, and C3) and Ubá (B2, B3, D2, and D3). Black is the absence of S and Ca. Chlamydospores (c), fungal hyphae (f), iron (Fe), magnesium $(\mathrm{Mg})$, manganese $(\mathrm{Mn})$, medullary radius $(\mathrm{mr})$, parenchyma cells $(\mathrm{pc})$, potassium $(\mathrm{K})$, tyloses $(\mathrm{t})$, and xylem vessels $(\mathrm{xv})$. Scale bars $=30 \mu \mathrm{m}$. 

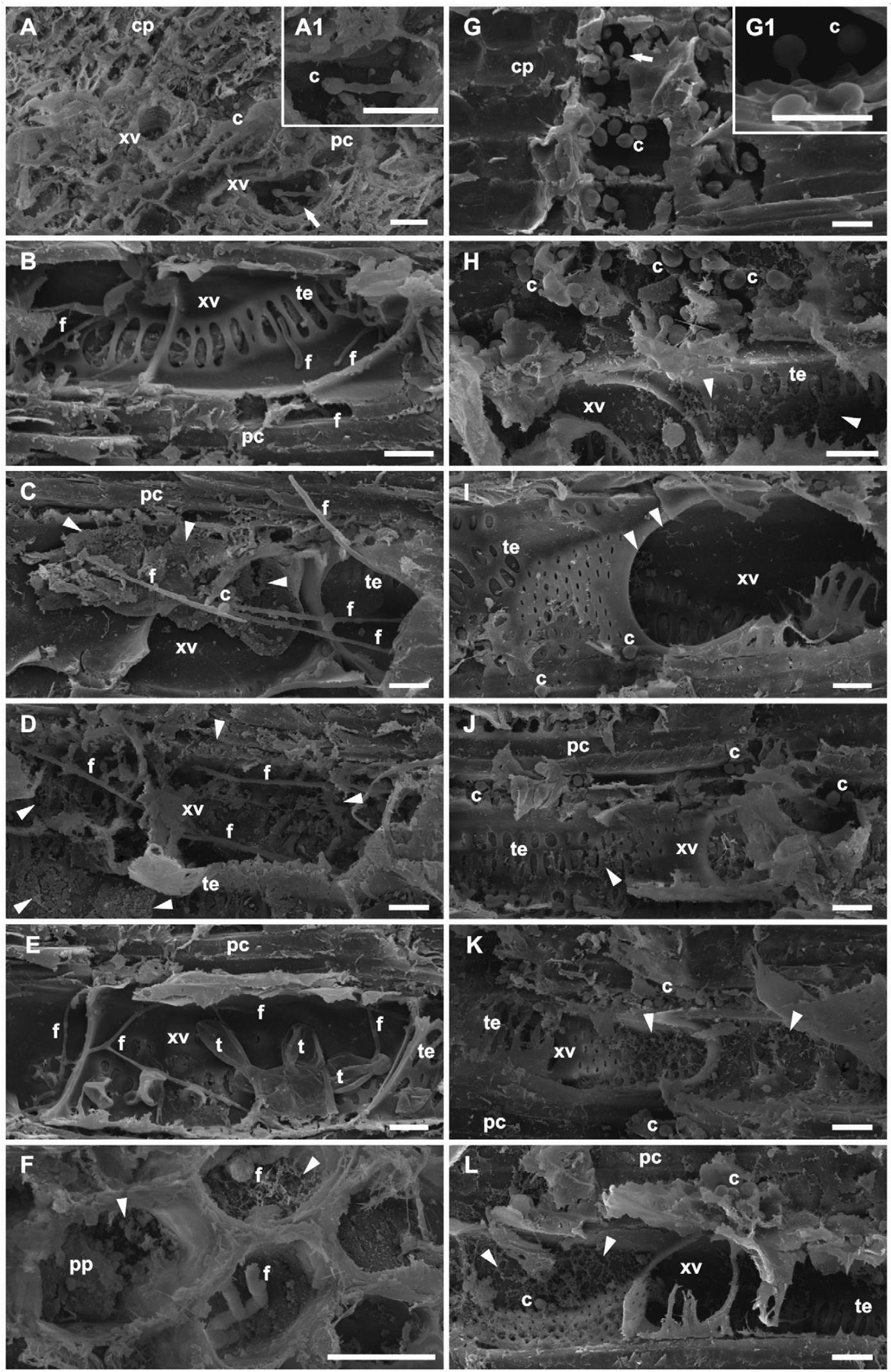

Fig. 6. Scanning electron micrographs of $\mathbf{A}$ and $\mathbf{F}$, transverse and $\mathbf{B}$ to $\mathbf{E}$ and $\mathbf{G}$ to $\mathbf{L}$, longitudinal sections of stem tissue from $\mathbf{A}$ to $\mathbf{F}$, Haden and $\mathbf{G}$ to $\mathbf{L}$, Ubá mango at 22 days after inoculation with Ceratocystis fimbriata. A and A1, Chlamydospores (aleurioconidia) already formed or in the process of formation (arrow) were observed in the cortical parenchyma and in the xylem vessels. B, Fungal hyphae colonized the parenchyma cells and the xylem vessels. In the xylem vessels, fungal hyphae in tracheal elements and in adjacent areas can be observed. $\mathbf{C}$ and $\mathbf{D}$, Long fungal hyphae and chlamydospores grew abundantly in the xylem vessels that were also obstructed by intense deposition of polysaccharide gels (arrowheads). E, Xylem vessels were obstructed by long fungal hyphae and large tyloses. F, Hyphae of $C$. fimbriata extensively colonized the pit parenchyma. Polysaccharide gels (arrowheads) were observed in certain cells of the pit parenchyma. G and G1, Many chlamydospores already formed or in process of formation (arrow) were observed in the cortical parenchyma. $\mathbf{H}$ to $\mathbf{L}$, Chlamydospores were observed in the parenchyma cells and in the xylem vessels, and several appeared to have formed in chains. Polysaccharide gels (arrowheads) were rarely deposited in the xylem vessels. Chlamydospores (c), cortical parenchyma (cp), fungal hyphae (f), parenchyma cells (pc), pith parenchyma (pp), polysaccharide gels (pg), tracheal elements (te), tyloses (t), and xylem vessels (xv). Scale bars $=20 \mu \mathrm{m}$. 

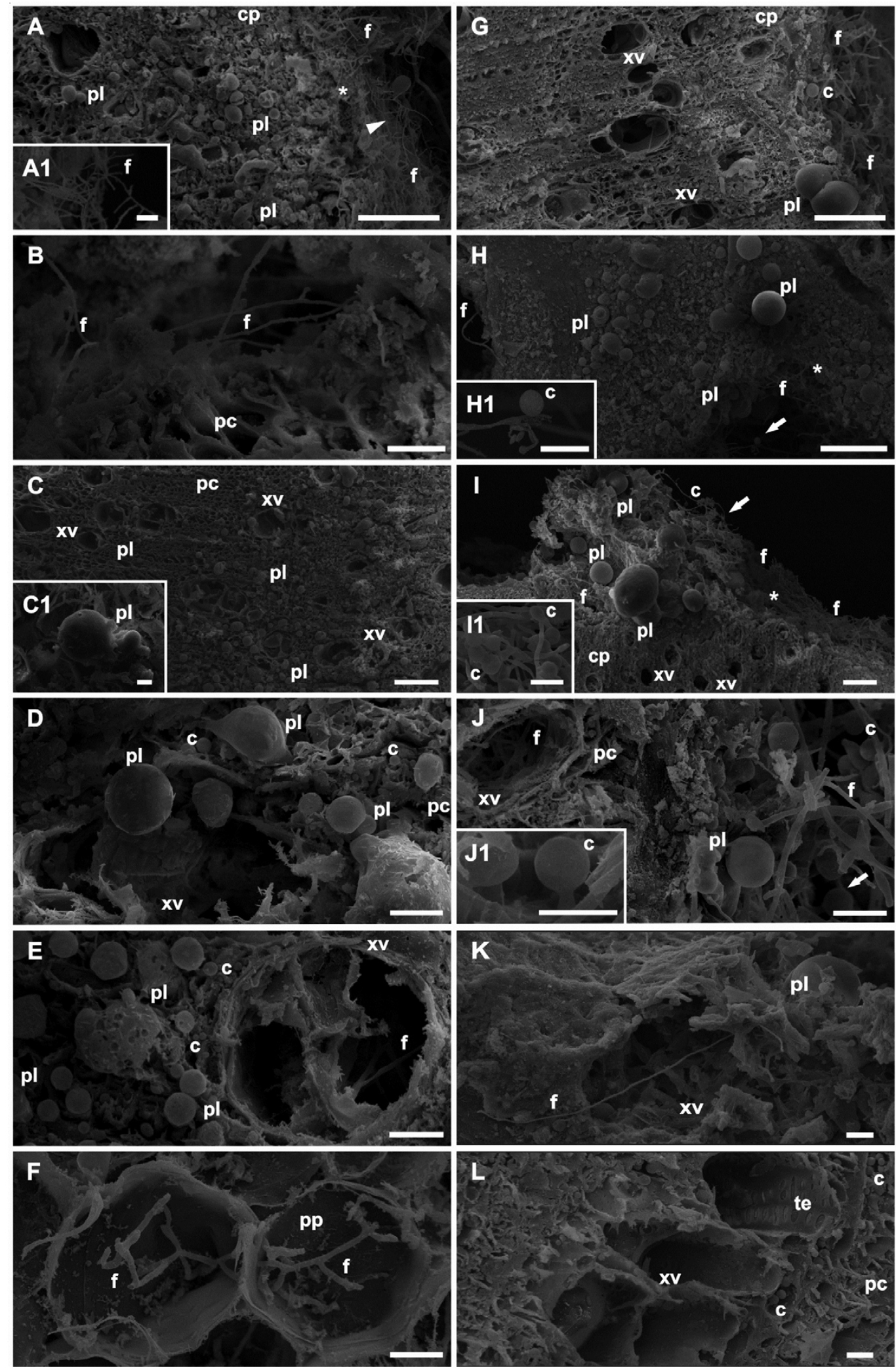

Fig. 7. Scanning electron micrographs of $\mathbf{A}$ to $\mathbf{J}$, transverse and $\mathbf{K}$ and $\mathbf{L}$, longitudinal sections of stem tissue from $\mathbf{A}$ to $\mathbf{F}$, Haden and $\mathbf{G}$ to $\mathbf{L}$, Ubá mango at 29 days after inoculation with Ceratocystis fimbriata. A, A1, and B, Fungal hyphae grew abundantly in the cortical parenchyma and adjacent to the xylem vessels. Many long fungal hyphae (arrowheads) and perithecia-like structures were observed proximal to the stem region where the inoculation occurred (asterisks). C and C1, Many perithecia-like structures were visible in the parenchyma cells and in the xylem vessels in the radial direction. D and E, Chlamydospores (aleurioconidia) and perithecia-like structures were abundantly visible in the parenchyma cells among the xylem vessels. The fungal hyphae reached the xylem vessels distant from the inoculation point. F, Hyphae of $C$. fimbriata extensively colonized the pit parenchyma. G, H, H1, I, I1, J, and J1, Fungal hyphae, perithecia-like structures, and chlamydospores formed or in the process of formation (arrow) were visible in the cortical parenchyma and in the xylem vessels proximal to the stem region where the inoculation occurred (asterisks). $\mathrm{K}$ and L: Xylem vessels distal to the inoculation point were free of any occlusion but fungal hyphae were observed in a few xylem vessels. Chlamydospores were found in the parenchyma cells adjacent to the xylem vessels. Chlamydospores (c), cortical parenchyma (cp), fungal hyphae (f), parenchyma cells (pc), perithecia-like structures (pl), pith parenchyma (pp), and xylem vessels (xv). Scale bars: A1, $\mathrm{B}, \mathrm{C} 1, \mathrm{D}, \mathrm{E}, \mathrm{F}, \mathrm{H} 1, \mathrm{I} 1, \mathrm{~J}, \mathrm{~J} 1, \mathrm{~K}$, and $\mathrm{L}=20 \mu \mathrm{m}$ and $\mathrm{A}, \mathrm{C}, \mathrm{G}, \mathrm{H}$, and $\mathrm{I}=100 \mu \mathrm{m}$. 

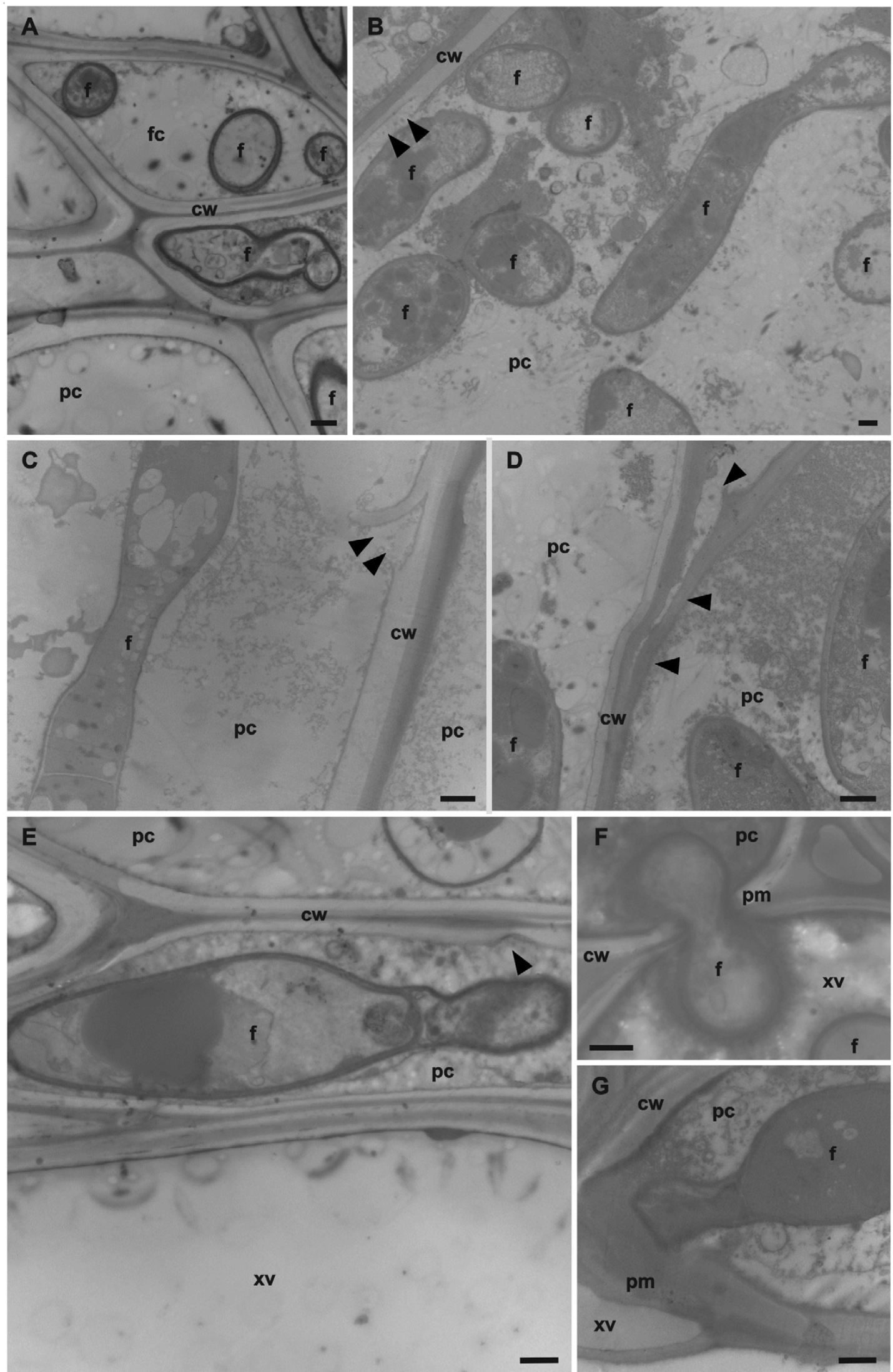

Fig. 8. Transmission electron micrographs of $\mathbf{A}, \mathbf{E}$, and $\mathbf{F}$, transverse and $\mathbf{B}, \mathbf{C}, \mathbf{D}$, and $\mathbf{G}$, longitudinal sections of stem tissue from Haden mango 22 days after inoculation with Ceratocystis fimbriata. A, Fungal hyphae extensively colonized the fiber cells. B to D, Long and thick fungal hyphae that broadly invaded the parenchyma cells and caused intense degradation of host cell walls (arrowheads). E, Long and thick fungal hyphae grew in the parenchyma cells adjacent to the xylem vessels, and the cell wall showed signs of degradation (arrowhead). F, Fungal hyphae penetrated the cell wall between the parenchyma cells and the xylem vessels. Note the extreme constriction of the fungal cell wall as the fungus passes through the pit membrane. G, Thickened fungal hyphae adhered to the pit membrane before reaching the xylem vessels. Host cell wall (cw), fiber cells (fc), fungal hyphae (f), parenchyma cells (pc), pit membrane (pm), and xylem vessels (xv). Scale bars $=1 \mu \mathrm{m}$. 

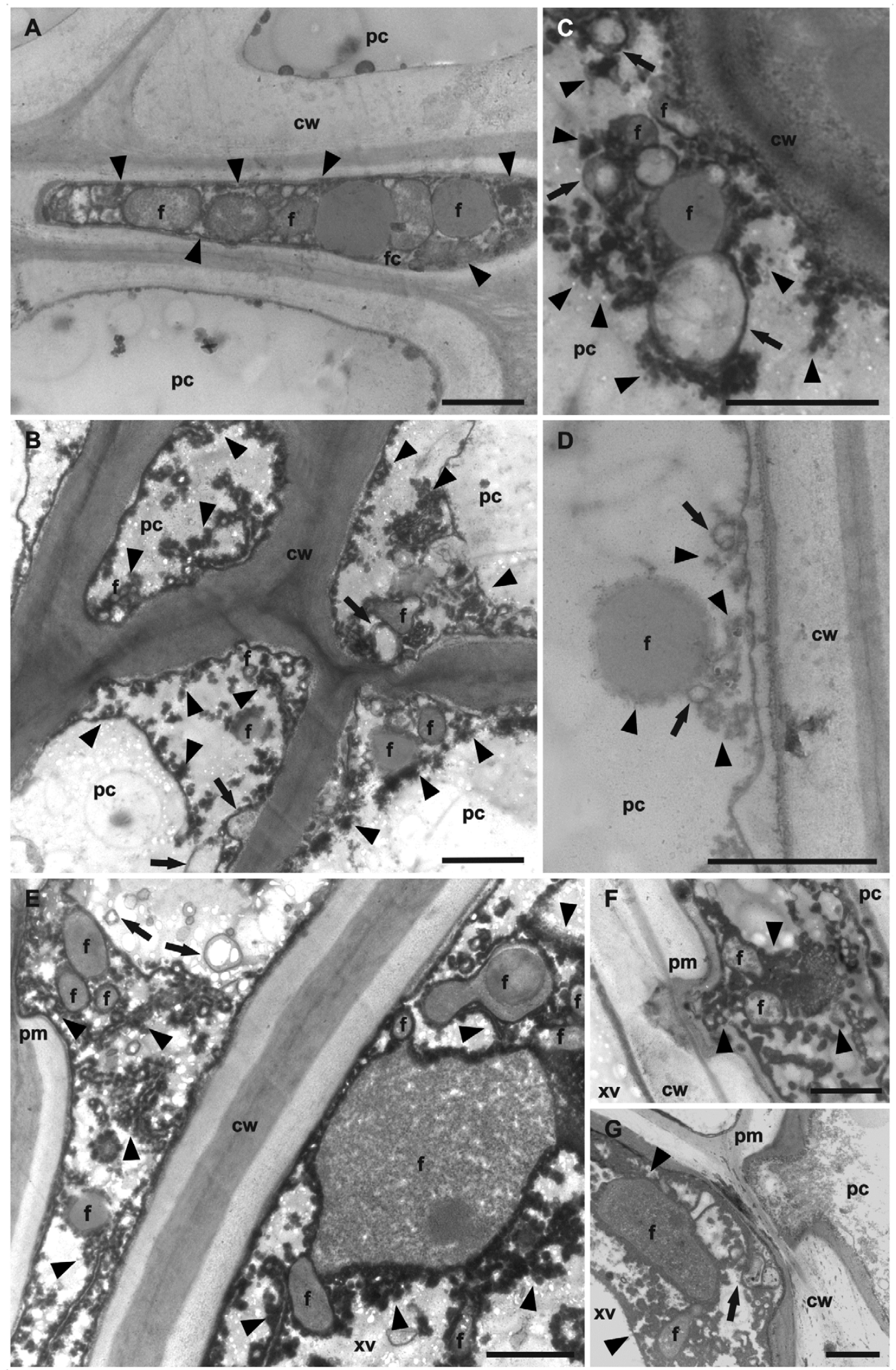

Fig. 9. Transmission electron micrographs of $\mathbf{A}, \mathbf{D}, \mathbf{F}$, and $\mathbf{G}$, transverse and $\mathbf{B}, \mathbf{C}$, and $\mathbf{E}$, longitudinal sections of stem tissue from Ubá mango 22 days after inoculation with Ceratocystis fimbriata. A, Amorphous granular material (arrowheads) accumulated in the fiber cells and regularly interacted with fungal hyphae and the host cell wall. B, Fungal hyphae and the cell wall of the parenchyma cells were surrounded by dense amorphous granular material (arrowheads). Some fungal hyphae appeared dead (arrows). C and D, Fungal hyphae in the parenchyma cells were trapped by the amorphous granular material (arrowheads) and were often killed (arrows). E and F, Fungal hyphae attempting to penetrate the pit membranes were impeded by the amorphous granular material (arrowheads), and several hyphae appeared dead (arrows). G, Fungal hyphae in the xylem vessels were often surrounded by dense amorphous granular material (arrowheads) and several hyphae appeared dead (arrow). Host cell wall (cw), fiber cells (fc), fungal hyphae (f), parenchyma cells (pc), pit membrane (pm), and xylem vessels (xv). Scale bars $=1 \mu \mathrm{m}$. 
parenchyma cell walls of Ubá were less degraded and were frequently encrusted by amorphous granular material. Degradation of cell walls is a typical feature reported in interactions between pea and F. oxysporum f. sp. pisi (7), tomato and V. albo-atrum (8) and $F$. oxysporum f. sp. lycopersici (33), and American elm and O. ulmi (35). Wall degradation is often attributed to release into the vascular fluid of cell-wall-degrading enzymes produced by pathogens $(3,13,33,44)$. Uritani and Stahmann $(54)$ reported that C. fimbriata produces pectinases in culture medium and in cells of the sweet potato that the fungus has penetrated. In the present study, the absence of damage to cell walls of the Ubá was most likely due to the protective nature of the amorphous granular material that prevented degradation by fungal hyphae and protected the host cell walls.

High levels of insoluble $\mathrm{Ca}$ were found in Ubá stem tissue colonized by $C$. fimbriata. High levels of $\mathrm{Ca}$ are associated with resistance to cell-wall-degrading enzymes produced by pathogens $(3,13,28,39)$. This is thought to occur because Ca bridges form between carboxyls of adjacent pectic chains in the host cell walls, making these well less accessible to the lytic enzymes released by the pathogens $(3,13,28,39)$. Corden and Edgington (16) found that the resistance of tomato plants to $F$. oxysporum $\mathrm{f}$. sp. lycopersici was due to an increase in calcium pectate that reduced the susceptibility of the pectin to degradation by the pectic enzymes produced by the vascular pathogen. Most likely, the tissues of Ubá containing high levels of $\mathrm{Ca}$ were more resistant to mango wilt because the cell wall strength hampered activity of cell-walldegrading enzymes of $C$. fimbriata.

Fungal hyphae penetrated the pit membranes of the stem tissue of Haden whereas, in tissue of Ubá, fungal penetration was often impeded by amorphous granular material. The pit membrane has a middle lamella and a primary cell wall designed to facilitate water flow between neighboring conduits and to prevent spread of gas bubbles causing a gas embolism (25). Various vascular pathogens can degrade the pit membrane and spread through intervessel colonization $(8,35,36)$. Pit penetration in susceptible tomato cultivars was achieved by constricted hyphae of $F$. oxysporum f. sp. lycopersici and V. albo-atrum without impediment by their hosts (8). However, in resistant plants, protective layers adjacent to pit membranes in parenchyma cells adjacent to the xylem vessels were formed in response to attack by several vascular pathogens $(8,35,36,38)$. Often, these layers of amorphous material are not found in noninfected vascular tissue but, in infected tissue, layers of amorphous materials protect vessels of adjacent tissue from pathogen invasion $(8,35,36,38)$. Generally, the difference between resistant and susceptible plants is related to the degree of phenolic infusion, lignification, or incorporation of $\mathrm{Ca}$ ions into the pit membrane $(7,8,35)$. In the present study, the deposition of phenolic-like compounds in the pit membranes and high levels of $\mathrm{S}$ and $\mathrm{Ca}$ in the stem tissue of Ubá helped explain the reduced $C$. fimbriata colonization in the xylem vessels and the absence of wilted plants.

In conclusion, marked differences at the cellular level in the stem tissue of the two mango cultivars during the infection process of $C$. fimbriata were noticed. In the resistant Ubá, there was less fungal colonization, reduced stem tissue necrosis, and absence of wilted plants when compared with the susceptible Haden. These results revealed that the barrier zones, deposition of $\mathrm{S}$ and $\mathrm{Ca}$, and accumulation of phenolic-like compounds played a pivotal role in the defense of mango plants against infection by C. fimbriata. These results indicate that mango wilt resistance through a plant breeding program and nutritional enhancement are feasibly possible.

\section{ACKNOWLEDGMENTS}

F. A. Rodrigues thanks $\mathrm{CNPq}$ for his fellowship. L. Araujo was supported by CNPq. This study was supported by a grant from Vale S.A. to F. A. Rodrigues. We thank the "Núcleo de Microscopia e Microanálise" of the Federal University of Viçosa for the use of the equipment, A. C. Alfenas and L. S. S. Oliveira for kindly providing the isolate of $C$. fimbriata used in this study, and L. E. Datnoff and R. J. Zeyen for their review and many suggestions that have significantly improved the manuscript.

\section{LITERATURE CITED}

1. Al-Sadi, A. M., Al-Ouweisi, F. A., Al-Shariani, N. K., Al-Adawi, A. O., Kaplan, E. J., and Deadman, M. L. 2010. Histological changes in mango seedlings following infection with Ceratocystis manginecans, the cause of mango decline. J. Phytopathol. 158:738-743.

2. Aoun, M., Rioux, D., Simard, M., and Bernier, L. 2009. Fungal colonization and host defense reactions in Ulmus americana callus cultures inoculated with Ophiostoma novo-ulmi. Phytopathology 99:642-650.

3. Bateman, D. F., and Millar, R. L. 1966. Pectic enzymes in tissue degradation. Annu. Rev. Phytopathol. 4:119-144.

4. Bélanger, R. R., Benhamou, N., and Menzies, J. G. 2003. Cytological evidence of an active role of silicon in wheat resistance to powdery mildew (Blumeria graminis f. sp. tritici). Phytopathology 93:402-412.

5. Benhamou, N., and Bélanger, R. R. 1998. Benzothiadiazole-mediated induced resistance to Fusarium oxysporum f. sp. radicis-lycopersici in tomato. Plant Physiol. 118:1203-1212.

6. Biggs, A. R. 1992. Anatomical and physiological responses of bark tissues to mechanical injury. Pages 13-36 in: Defense Mechanisms of Woody Plants Against Fungi. R. A. Blanchette and A. T. Biggs, eds. Springer-Verlag, Berlin.

7. Bishop, G. D., and Cooper, R. M. 1983. An ultrastructural study of root invasion in three vascular wilt diseases. Physiol. Plant Pathol. 22:15-27.

8. Bishop, G. D., and Cooper, R. M. 1983. An ultrastructural study of vascular colonization in three vascular wilt diseases I. Colonization of susceptible cultivars. Physiol. Plant Pathol. 23:323-343.

9. Blanchette, R. A. 1992. Anatomical responses of xylem to injury and invasion by fungi. Pages 76-95 in: Defense Mechanisms of Woody Plants Against Fungi. R. A. Blanchette and A. T. Biggs, eds. Springer-Verlag, Berlin

10. Bozzola, J. J., and Russell, L. D. 1999. Electron Microscopy: Principles and Techniques for Biologists, 2nd ed. Jones and Bartlett Publishers, Boston.

11. Bucciarelli, B., Ostry, M. E., Fulcher, R. G., Anderson, N. A., and Vance, C. P. 1999. Histochemical and microspectrophotometric analyses of early wound responses of resistant and susceptible Populus tremuloides inoculated with Entoleuca mammata (= Hypoxylon mammatum). Can. J. Bot. 77:548-555.

12. Carvalho, C. R. L., Rossetto, C. J., Mantovani, D. M. B., Morgano, M. A., Castro J. V., and Bortoletto N. 2004. Avaliação de cultivares de mangueira selecionadas pelo Instituto Agronômico de Campinas comparadas a outras de importância comercial. Rev. Bras. Frutic. 26:264-271.

13. Collmer, A., and Keen N. T. 1986. The role of pectic enzymes in plant pathogenesis. Annu. Rev. Phytopathol. 24:383-409.

14. Cooper, R. M., Resende, M. L. V., Flood, J., Rowan, M. G., Beale, M. H., and Potter, U. 1996. Detection and cellular localization of elemental sulphur in disease resistant genotypes of Theobroma cacao. Nature 379:159-162.

15. Cooper, R. M., and Wood R. K. S. 1974. Scanning electron microscopy of Verticillium albo-atrum in xylem vessels of tomato plants. Physiol. Plant Pathol. 4:443-446.

16. Corden, M. E., and Edgington, L. V. 1960. A calcium requirement for growth-regulator-induced resistance to Fusarium wilt of tomato. Phytopathology 50:625-626.

17. Datnoff, L. E., Elmer, W. H., and Huber, D. M. 2007. Mineral Nutrition and Plant Disease. The American Phytopathological Society Press, St. Paul, MN.

18. Dhingra, O. D., and Sinclair, J. B. 1995. Basic Plant Pathology Methods. Lewis Publisher, Boca Raton, FL.

19. Dixon, R. A., and Paiva, N. L. 1995. Stress induced phenylpropanoid metabolism. Plant Cell 7:1085-1097.

20. Duchesne, L. C., Hubbes, M., and Jeng, R. S. 1992. Biochemistry and molecular biology of defense reactions in the xylem of angiosperm trees. Pages 133-142 in: Defense Mechanisms of Woody Plants Against Fungi. R. A. Blanchette and A. T. Biggs, eds. Springer-Verlag, Berlin.

21. Eynck, C., Koopmann, B., Karlovsky, P., and von Tiedemann, A. 2009. Internal resistance in winter oilseed rape inhibits systemic spread of the vascular pathogen Verticillium longisporum. Phytopathology 99:802-811.

22. FAO. 2013. Medium-term prospects for agricultural Commdities. In: Food and Agriculture Organization of the United Nations. http://www. fao.org/docrep/006/y5143e/y5143e1a.htm

23. Ferreira, E. M., Harrington, T. C., Thorpe, D. J., and Alfenas, A. C. 2010. 
Genetic diversity and interfertility among highly differentiated populations of Ceratocystis fimbriata in Brazil. Plant Pathol. 59:721-735.

24. Goldstein, J., Newbury, D., Joy, D., Lyman, C., Echlin, P., Lifshin, E., Sawyer, L., and Michael, J. 2003. Scanning Electron Microscopy and Xray Microanalysis, 3rd ed. Kluwer Academic/Plenum Publishers, New York.

25. Gortan, E., Nardini, A., Salleo, S., and Jansen, S. 2011. Pit membrane chemistry influences the magnitude of ion-mediated enhancement of xylem hydraulic conductance in four Lauraceae species. Tree Physiol. 31:48-58.

26. Hall, C., Heath, R., and Guest, D. I. 2011. Rapid and intense accumulation of terpenoid phytoalexins in infected xylem tissues of cotton (Gossypium hirsutum) resistant to Fusarium oxysporum f. sp. vasinfectum. Physiol. Mol. Plant Pathol. 76:182-188.

27. Haneklaus, S., Bloem, E., and Schnug, E. 2007. Sulfur and plant disease. Pages 101-118 in: Mineral Nutrition and Plant Disease. L. E. Datnoff, W. H. Elmer, and D. M. Huber, eds. American Phytopathological Society Press, St. Paul, MN.

28. Huang, J. S. 2001. Plant Pathogenesis and Resistance: Biochemistry and Physiology of Plant-Microbe Interactions. Kluwer Academic Publishers, Norwell, Madison, WI.

29. Koga, H., Zeyen, R. J., Bushnell, W. R., and Ahlstrand, G. G. 1988. Hypersensitive cell death, autofluorescence, and insoluble silicon accumulation in barley leaf epidermal cells under attack by Erysiphe graminis f. sp. hordei. Physiol. Mol. Plant Pathol. 32:395-409.

30. Lecourieux, D., Ranjeva, R., and Pugin, A. 2006. Calcium in plant defence-signalling pathways. New Phytol. 171:249-269.

31. Liu, F. X., Fu, S. F., Bi, X. F., Chen, F., Liao, X. J., Hu, X. S., and Wu, J. H. 2013. Physico-chemical and antioxidant properties of four mango (Mangifera indica L.) cultivars in China. Food Chem. 138:396-405.

32. Merrill, W. 1992. Mechanisms of resistance to fungi in woody plants: a historical perspective. Pages 1-11 in: Defense Mechanisms of Woody Plants Against Fungi. R. A. Blanchette and A. T. Biggs, eds. SpringerVerlag, Berlin.

33. Mussell, H. W., and Green, R. J. J. 1970. Host colonization and polygalacturonase production by two tracheomycotic fungi. Phytopathology 60:192-195.

34. Nicholson, R. L., and Hammerschmidt, R. 1992. Phenolic compounds and their role in disease resistance. Annu. Rev. Phytopathol. 30:369-389.

35. Ouellette, G. B., and Rioux, D. 1992. Anatomical and physiological aspects of resistance to Dutch Elm disease. Pages 257-301 in: Defense Mechanisms of Woody Plants Against Fungi. R. A. Blanchette and A. T. Biggs, eds. Springer-Verlag, Berlin.

36. Ouellette, G. B., Rioux, D., Simard, M., and Cherif, M. 2004. Ultrastructural and cytochemical studies of host and pathogens in some fungal wilt diseases: retro- and introspection towards a better understanding of DED. Invest. Agrar. Sist. Recur. For. 13:119-145.

37. Parke, J. L., Oh, E., Voelker, S., Hansen, E. M., Buckles, G., and Lachenbruch, B. 2007. Phytophthora ramorum colonizes tanoak xylem and is associated with reduced stem water transport. Phytopathology 97:1558-1567.

38. Pegg, G. F. 1976. Transmission electron microscopy of Verticillium alboatrum hyphae in xylem vessels of tomato plants. Physiol. Plant Pathol. 8:221-224.

39. Rahman, M., and Punja, Z. K. 2007. Calcium and plant disease. Pages 7993 in: Mineral Nutrition and Plant Disease. L. E. Datnoff, W. H. Elmer, and D. M. Huber, eds. American Phytopathological Society, St. Paul, MN.

40. Ribeiro, I. J. A. 2005. Doenças da mangueira (Mangifera indica L.).
Pages 457-465 in: Manual de Fitopatologia: Doenças das Plantas Cultivadas. H. Kimati, L. Amorim, A. Bergamin-Filho, L. E. A. Camargo, and J. A. M. Rezende, eds. Agronômica Ceres, São Paulo, Brazil.

41. Ribeiro, I. J. A., Rossetto, C. J., Sabino, J. C., and Gallo, P. B. 1986. Seca da mangueira: VIII. Resistência de porta-enxertos de mangueira ao fungo Ceratocystis fimbriata Ell. \& Halst. Bragantia 45:317-322.

42. Ribeiro, S. M. R., Barbosa, L. C. A., Queiroz, J. H., Knodler, M., and Schieber, A. 2008. Phenolic compounds and antioxidant capacity of Brazilian mango (Mangifera indica L.) varieties. Food Chem.110:620626.

43. Rioux, D., and Baayen, R. P. 1997. A suberized perimedullary reaction zone in Populus balsamifera novel for compartmentalization in trees. Trees 11:389-403.

44. Rioux, D., Nicole, M., Simard, M., and Ouellette, G. B. 1998. Immunocytochemical evidence that secretion of pectin occurs during gel (gum) and tylosis formation in trees. Phytopathology 88:494-505.

45. Rodrigues, F. A., Benhamou, N., Datnoff, L. E., Jones, J. B., and Bélanger, R. R. 2003. Ultrastructural and cytochemical aspects of siliconmediated rice blast resistance. Phytopathology 93:535-546.

46. Rossetto, C. J., Ribeiro, I. J. A., Igue, T., and Gallo, P. B. 1996. Seca-damangueira XV. Resistência varietal a dois isolados de Ceratocystis fimbriata. Bragantia 55:117-121.

47. Scalet, M., Crivellato, E., and Mallardi, F. 1989. Demonstration of phenolic compounds in plant tissues by an osmium-iodide postfixation procedure. Stain Technol. 64:273-290.

48. Shaner, G., and Finney, R. E. 1977. The effect of nitrogen fertilization on the expression of slow-mildewing resistance in Knox wheat. Phytopathology 70:1183-1186.

49. Simard, M., Rioux, D., and Laflamme, G. 2001. Formation of lignosuberized tissues in jack pine resistant to the European race of Gremmeniella abietina. Phytopathology 91:1128-1140.

50. Southerton, S. G., and Deverall, B. J. 1990. Histochemical and chemical evidence for lignin accumulation during the expression of resistance to leaf rust fungi in wheat. Physiol. Mol. Plant Pathol. 36:483-494.

51. Souza, A. G. C., Rodrigues, F. A., Maffia, L. A., and Mizubuti, E. S. G. 2011. Infection process of Cercospora coffeicola on coffee leaf. J. Phytopathol. 159:6-11.

52. Sugimoto, T., Watanabe, K., Yoshida, S., Aino, M., Furiki, M., Shiono, M., Matoh, T., and Biggs, A. R. 2010. Field application of calcium to reduce Phytophthora stem rot of soybean, and calcium distribution in plants. Plant Dis. 94:812-819.

53. Tippett, J. T., and Shigo, A. L. 1981. Barrier zone formation: a mechanism of tree defense against vascular pathogens. IAWA Bull. 4:163-168.

54. Uritani, I., and Stahmann, M. A. 1961. Pectolytic enzymes of Ceratocystis fimbriata. Phytopathology 51:277-285.

55. Van Wyk, M., Al Adawi, A. O., Khan, I. A., Deadman, M. L., Al Jahwari, A. A., Wingfield, B. D., Ploetz, R., and Wingfield, M. J. 2007. Ceratocystis manginecans sp. nov., causal agent of a destructive mango wilt disease in Oman and Pakistan. Fungal Divers. 27:213-230.

56. Viégas, A. P. 1960. Seca da mangueira. Bragantia 19:163-182.

57. Williams, J. S., Hall, S. A., Hawkesford, M. J., Beale, M. H., and Cooper, R. M. 2002. Elemental sulfur and thiol accumulation in tomato and defense against a fungal vascular pathogen. Plant Physiol. 128:150-159.

58. Zeyen, R. J., Ahlstran, G. G., and Carver, T. L. W. 1993. X-ray microanalysis of frozen-hydrated, freeze-dried, and critical point dried leaf specimens: determination of soluble and insoluble chemical elements at Erysiphe graminis epidermal cell papilla sites in barley isolines containing M1-o and $m l-o$ alleles. Can. J. Bot. 71:284-296. 